\title{
Correction to: Cardiovascular disease (CVD): assessment, prediction and policy implications
}

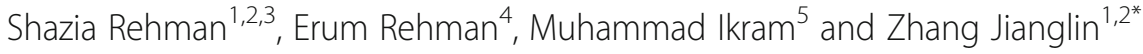

\author{
Correction to: BMC Public Health 21, 1299 (2021) \\ https://doi.org/10.1186/s12889-021-11334-2
}

It was highlighted that in the original article [1] under the section Relative growth rate (RGR) and doubling time (Dt) analysis, the equations erroneously contained some red text. In Fig.3 ref. [43] was also cited incorrectly. The correct reference in Fig. 3 is 44 . The original article has been updated.
44. Hessami A, Shamshirian A, Heydari K, Pourali F, Alizadeh-Navaei R, Moosazadeh M, et al. Cardiovascular diseases burden in COVID-19: Systematic review and meta-analysis: medRxiv; 2020. https://doi.org/10.101 6/j.ajem.2020.10.022.

\section{Author details}

'Department of Dermatology, Shenzhen People's Hospital, The Second Clinical Medical College, Jinan University, The first Affiliated Hospital, Southern University of Science and Technology, Shenzhen 518020,

Guangdong, China. ${ }^{2}$ Candidate Branch of National Clinical Research Center for Skin Diseases, Shenzhen 518020, Guangdong, China. ${ }^{3}$ Department of Biostatistics, School of Public Health, Harbin Medical University, Harbin, China. ${ }^{4}$ Department of Mathematics\& Statistics, School of Statistics, Southwestern University of Finance and Economics, Chengdu, China. ${ }^{5}$ College of Management, Research Institute of Business Analytics and Supply Chain, Management, Shenzhen University, Shenzhen, China.

Published online: 12 July 2021

\section{Reference}

1. Rehman, et al. Cardiovascular disease (CVD): assessment, prediction and policy implications. BMC Public Health. 2021;21:1299. https://doi.org/10.11 86/s12889-021-11334-2.

43. Guzik TJ, Mohiddin SA, Dimarco A, Patel V, Savvatis K, Marelli-Berg FM, et al. COVID-19 and the cardiovascular system: implications for risk assessment, diagnosis, and treatment options. Cardiovasc Res. 2020;116(10):1666-87. https://doi.org/10.1093/cvr/cvaa106.

The original article can be found online at https://doi.org/10.1186/s12889021-11334-2.

* Correspondence: zhangjl@csu.edu.cn

'Department of Dermatology, Shenzhen People's Hospital, The Second Clinical Medical College, Jinan University, The first Affiliated Hospital, Southern University of Science and Technology, Shenzhen 518020, Guangdong, China

${ }^{2}$ Candidate Branch of National Clinical Research Center for Skin Diseases, Shenzhen 518020, Guangdong, China

Full list of author information is available at the end of the article

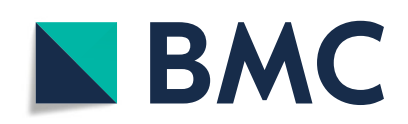

(c) The Author(s). 2021 Open Access This article is licensed under a Creative Commons Attribution 4.0 International License, which permits use, sharing, adaptation, distribution and reproduction in any medium or format, as long as you give appropriate credit to the original author(s) and the source, provide a link to the Creative Commons licence, and indicate if changes were made. The images or other third party material in this article are included in the article's Creative Commons licence, unless indicated otherwise in a credit line to the material. If material is not included in the article's Creative Commons licence and your intended use is not permitted by statutory regulation or exceeds the permitted use, you will need to obtain permission directly from the copyright holder. To view a copy of this licence, visit http://creativecommons.org/licenses/by/4.0/. The Creative Commons Public Domain Dedication waiver (http://creativecommons.org/publicdomain/zero/1.0/) applies to the data made available in this article, unless otherwise stated in a credit line to the data. 